\title{
FAKTOR YANG MEMPENGARUHI IBU DALAM PEMBERIAN NUTRISI PADA BADUTA (BAWAH DUA TAHUN) DI KABUPATEN JOMBANG
}

\author{
Factors Affecting Mothers in Providing Nutrition to Under Two Years \\ In Jombang
}

Ririn Probowati, Heri Wibowo, Monika Sawitri Prihatini, Mamik Ratnawati

\author{
STIKes Pemkab Jombang
}

\section{Riwayat artikel}

Diajukan: 11 Agustus 2021

Diterima: 16 September

2020

\section{Penulis Korespondensi:}

- Ririn Probowati

- STIKEs Pemkab Jombang

e-mail:

ririn_probowati@yahoo.com

\section{Kata Kunci:}

factor, Nurisi giving, under two years

\begin{abstract}
Abstrak
Pendahuluan : Masalah gangguan gizi pada anak-anak di Indonesia menempati urutan tertinggi dengan berbagai banyak factor yang mempengaruhi status gizi. Pemberian Nurisi yang di lakukan oleh ibu akan mempengaruhi status gizi Baduta. Tujuan penelitian untuk mengetahui faktor yang mempengaruhi ibu dalam pemberian nutisi Baduta (bawah dua tahun) di Kabupaten Jombang. Metode: case control dengan rancangan cross sectional. Populasi: semua ibu yang mempunyai baduta di kabupaten Jombang tahun 2019 sejumlah 9.682 anak. Sampel sebagian Ibu yang mempunyai baduta sebesar 242 dengan convenience sampling. Varibel penelitian penyakit, Pendidikan dan pengetahuan orang tua, jumlah tanggung dan pendapatan, budaya keluarga. Pengambilan data menggunakan instrument. Analisa data menggunakan Uji statistik uji regresi logistik berganda . Hasil: Ada hubungan antara penggunaan fasilitas kesehatan, pengetahuan, tanggungan, budaya, penghasilan keluarga dan budaya. Faktor penggunaan fsilitas kesehatan mempunyai hubungan paling kuat mempengaruhi status gizi baduta. dengan OR 8.235.. Kesimpulan: Semakin sering ibu menggunakan fasilitas Kesehatan yang terdapat di masyarakat dapat berupa kegiatan di POSYANDU, BKB (bina keluarga Balita) dan PAUD (Pendidikan anak usia dini), Dalam kegiatan tersebut yang di lakukan setiap bulan sekali dapat meningkatakan stimulasi peningkatan gizi, memonitor status gizi yang dilakukan oleh ibu yang berhubungan dengan pemberian nutrisi pada Baduta. Pemberian Nutrisi yang seusia dengan usia, jumlah, jenis, frekuensi pada Baduta yang di lakukan oleh ibu akan mempengaruhi status gizi badutai.
\end{abstract}

\section{Abstract}

Background: The problem of malnutrition in children in Indonesia ranks highest with many factors that affect nutritional status. Nurisi giving done by the mother will affect the nutritional status of Baduta. The purpose of the study was to find out the factors that affect the mother in the administration of clown nutisi (under two years) in Jombang Regency. Method: case control with cross sectional design. Population: all mothers who have children under two in Jombang district in 2019 totaling 9.682 children. The sample of some mothers who have children under two is 242 with convenience sampling. Varied disease research, Education and parental knowledge, amount of responsibility and income, family culture. Data retrieval using instruments. Data analysis using statistical test of multiple logistic regression test. Results: There is no relationship between disease factors, maternal education and nutritional status of clowns. There is a link between the use of health facilities, knowledge, dependents, culture, family income and culture The factor of using health facilities has the strongest relationship to influence the nutritional status of children under two. with an OR of 8,235. Conclusion:The more often mothers use health facilities available in the community, it can be in the form of activities at POSYANDU, BKB (toddler family development) and PAUD (early childhood education), In these activities which are carried out once a month can increase the stimulation of nutritional improvement, monitoring the nutritional status of mothers related to providing nutrition to under two years Provision of nutrition that is in accordance with the age, number, type, frequency of Baduta carried out by the mother will affect the nutritional status of under two years 


\section{PENDAHULUAN}

Baduta (Bawah dua tahun) merupakan 1000 hari pertama kehidupan merupakan periode mulai dari janin terbentuk sampai nak berusia 2 tahun. Pada periode ini merupakan periode terpenting pada masa pertumbuhan dan perkembangan sebagai individu penerus bangsa yang dapat diharapakan untuk mencetak generasi yang handal dalam persaingan di kancah global. Agar menghasilkan genarasi yang handal pada periode tersebut memerlukan stimulasi pertumbuhan dan perkembangan yang baik . Stimulasi pertumbuhan berupa pemberian gizi yang adekuat dan stimulasi perkembangan yang dilakukan oleh orang tua. Apabila balita tidak mendapatkan nutrisi yang adekuat akan berdampak pada gangguan pertumbuhan nampak pada berat badan dan tinggi badan yang tidak sesuai dengan usia

Jumlah Balita di negara berkembang Lebih dari 200 juta anak dan lebih dari sepertiganya mengalami gagal untuk mencapai potensi pertumbuhan dan perkembangan yang optimal dapat berupa kesehatan yang buruk, gizi buruk, defisiensi makro/mikronutrien, serta keterlambatan perkembangan pada periode penting tersebut (Ali, 2013)

Pertumbuhan anak balita sangat pesat sehingga memerlukan asupan zat gizi yang sesuai dengan kebutuhan balita. Ukuran keberhasilan dalam pemenuhan asupan zat gizi adalah status gizi yang dapat di pantau melalui KMS (Kartu Menuju Sehat) dengan memperhatikan tinggi badan dan berat badan. Anak yang mendapatkan asupan gizi baik akan mempunyai berat badan dan tinggi badan berada pada grafik KMS di warna kuning atau hijau. Bila anak mempunyai masalah gizi KMS akan mempunyai berat badan dan tinggi badan berada pada grafik garis merah yang di sebut anak mengalami BGM (Bawah Garis Merah).

Pertumbuhan anak-anak di negara berkembang salah satunya Indonesia ternyata masih terbelakang dibandingkan anak-anak di negara maju. Masalah kurang konsumsi pangan atau gizi harus diatasi sejak dini, jika kita menginginkan anak- anak Indonesia bertumbuh dan berkembang dengan baik dengan pesat (Khomsan, 2012). Masalah gizi merupakan masalah kesehatan masyarakat dimana penyebabnya dipengaruhi oleh beberapa faktor yang saling berkaitan, dan penangulangannya tidak dapat dilakukan melalui pendekatan medis maupun pelayanan keshatan lainnya. Masalah gizi bukan hanya menjadi masalah kesehatan masyarakat saja, tetapi juga menjadi masalah kemiskinan, pemerataan, dan masalah kesempatan kerja (Supariasa, Fajar dan Bakri, 2001)

Pertumbuhan anak sangat erat kaitannya dengan status gizi pada anak. Hasil Riskesdas dari tahun 2007 ke tahun 2013 menunjukkan fakta yang memprihatinkan dimana underweight meningkat dari $18,4 \%$ menjadi $19,6 \%$, stunting juga meningkat dari $36,8 \%$ menjadi $37,2 \%$, sementara wasting (kurus) menurun dari 13,6\% menjadi $12,1 \%$ (Badan Penelitian dan Pengembangan Kesehatan, 2019) Diwilayah Kabupaten Jombang dari tahun 2017 sampai tahun 2018 angka kejadian BGM naik. Pada tahun 2017 jumlah balita 39.528 balita dengan BGM sejumlah 472(0,6\%). Sedangkan Balita dengan BGM tahun 2018 di Kabupaten Jombang sejumlah 511 Balita. Jumlah Baduta (Bawah Dua tahun) sebanyak 9.682 Baduta (Dinas Kesehatan Kabupaten Jombang, 2018).

Septikasari (2018) mengungkapkan bahwa penyebab masalah gizi pada anak -anak dibagi menjadi dua yaitu penyebab langsung dan penyebab tidak langsung. Penyebab langsung meliputi konsumsi makanan yang buruk dan adanya penyakit. Bahkan antara asupan gizi dan penyakit terjadi interaksi yang saling menguatkan untuk memperburuk keadaan. Interkasi ini dapat berakibat fatal penyebab kematian dini pada anak-anak. Penyebab tidak langsung merupakan merupakan faktor yang mempengaruhi penyebab langsung. Seperti akses mendapatkan makanan yang kurang, perawatan dan pola asuh anak kurang, dan pelayanan kesehatan serta lingkungan buruk atau tidak mendukung kesehatan anak-anak.

Faktor inilah yang mempengaruhi rendah buruknya asupan makanan/gizi anak dan terjadinya penyakit pada anak-anak. (3) Penyebab mendasar terdiri dari dua hal, yakni faktor sumber daya potensial: yaitu sangat erat kaitannya dengan politik dan ideologi, suprastruktur, dan struktur ekonomi.dan faktor yang menyangkut sumber daya manusia yaitu pendidikan, pengetahuan, pendapatan keluarga, jumlah anggota keluarga yang menjadi tanggungan, budaya tentang makanan pada anak (Septikasari, 2018). Tujuan penelitian ini adalah menganalisis faktor yang 
mempengaruhi asupan gizi Baduta di Kabupaten Jombang

\section{METODE}

Desain penelitian ini adalah case control dengan pendekatan cross secional. Populasi yang diguankan adalah semua ibu yang mempunyai Baduta kabupaten Jombang 2019 sebanyak 9.682. Sampel adalah sebagian ibu yang mempunyai Baduta kabupaten Jombang 2019 sejumlah $2,5 \%$ dari 9.682 yaitu 242 responden. Waktu pengambila data bulan oktober - Desember 2019. Teknik sampling menggunakan tehnik convenience sampling

\section{Analisa data}

Analisa Univariat disajikan dalam nilai mean, standar deviasi, median, minimum dan maksimum. Analisa Bivariat hubungan variabel bebas dan variabel terikat dilakukan debgan uji chi-square. Pengambilan keputusan hipotesis dikatakan Ho diterima jika $p$-value $(0,05)$ dan Ho ditolak jika p-value < $(0,05)$. Analisa Multivariat menggunakan analisisa uji statistik Regresi Logistik Ganda. Jika nilai p-value < $(0,05)$ maka Ho ditolak. Berdasarkan hasil yang diperoleh dari analisa ini akan didapatkan variabel bebas yang paling dominan berhubungan dengan variabel terikat dengan melihat nilai OR (odd ratio) (Hidayat, 2014)

\section{HASIL}

Pada semua anak di bawah 2 tahun yang datang Di Posyandu saat di lakukan penelitian bulan oktober - Desember 2019 yang memenuhi kriteria anak tidak sedang sakit dan di bawa oleh orang tuanya sejumlah 242 anak

Tabel 1: Distribusi frekuensi data umum Responden 2019

\begin{tabular}{|l|l|l|l|}
\hline No. & Karakteristik Responden & $\begin{array}{l}\text { freku } \\
\text { ensi }\end{array}$ & $\begin{array}{l}\text { Presenta } \\
\text { se (\%) }\end{array}$ \\
\hline \multirow{2}{*}{1.} & Umur Ibu & 154 & 63.6 \\
& Umur 15- <30 Tahun & 98 & 36,4 \\
\hline \multirow{2}{*}{2.} & Umur 31-45 Tahun & 135 & 55,8 \\
& Umur Balita & 107 & 54,2 \\
\hline \multirow{2}{*}{3.} & Umur 12-24 Bulan & 102 & 42,1 \\
& Jenis Kelamin Baduta & 140 & 57,9 \\
\hline
\end{tabular}

Sumber : Data Primer 2019
Berdasarkan tabel 1 menunjukkan bahwa Sebagian besar (63.6\%) ibu berusia 15$<30$, Sebagian besar $(55,8 \%)$ Baduta usia $24-41$ bulan dan Sebagian besar $(57,9 \%)$ jenis kelamin perempuan.

Tabel 2 : Distribusi frekuensi responden berdasarkan data khusus tahun 2019 baduta di Jombang 2019

\begin{tabular}{|c|c|c|c|}
\hline No. & $\begin{array}{l}\text { Karakteristik } \\
\text { Responden }\end{array}$ & frekuensi & $\begin{array}{c}\text { Presentase } \\
(\%)\end{array}$ \\
\hline 1. & $\begin{array}{ll}\text { Ada faktor } \\
\text { penyaklit } \\
\text { Tidak ada faktor } \\
\text { penyakit }\end{array}$ & $\begin{array}{l}138 \\
104\end{array}$ & $\begin{array}{l}57 \\
53\end{array}$ \\
\hline 2. & $\begin{array}{l}\text { Sering } \\
\text { Menggunaklan } \\
\text { fasilitas layanan } \\
\text { kesehatan } \\
\text { Jarang } \\
\text { menggunakan } \\
\text { fasilitas layanan } \\
\text { kesehatan }\end{array}$ & $\begin{array}{l}200 \\
42\end{array}$ & $\begin{array}{l}82.6 \\
17.4\end{array}$ \\
\hline 3. & $\begin{array}{l}\text { Pendidikan } \\
\text { rendah } \\
\text { Pendidikan tinggi }\end{array}$ & $\begin{array}{c}184 \\
58\end{array}$ & $\begin{array}{l}76 \\
24\end{array}$ \\
\hline 4. & $\begin{array}{l}\text { Pengetahuan baik } \\
\text { Pengetahuan } \\
\text { cukup }\end{array}$ & $\begin{array}{l}141 \\
101\end{array}$ & $\begin{array}{l}34,1 \\
65,9\end{array}$ \\
\hline 5. & $\begin{array}{l}\text { Tanggungan } \\
\text { keluarga lebih dari } \\
5 \text { orang } \\
\text { Tanggungan } \\
\text { keluarga kurang } \\
\text { dari } 5 \text { orang } \\
\end{array}$ & $\begin{array}{l}82 \\
160\end{array}$ & $\begin{array}{l}33,9 \\
66,1\end{array}$ \\
\hline 6. & $\begin{array}{l}\text { Lebih besar /sama } \\
\text { dengan UMR } \\
\text { Kurang dari UMR }\end{array}$ & $\begin{array}{l}126 \\
116\end{array}$ & $\begin{array}{l}47,9 \\
52,1\end{array}$ \\
\hline 7 & $\begin{array}{lr}\text { Budaya } & \text { tentang } \\
\text { makanan } & \text { yang } \\
\text { baik } & \\
\text { Budaya } & \text { tentang } \\
\text { makan } & \text { yang } \\
\text { kurang baik } & \\
\end{array}$ & $\begin{array}{c}156 \\
86\end{array}$ & $\begin{array}{l}64,5 \\
35,5\end{array}$ \\
\hline 8 & $\begin{array}{l}\text { Status gizi baik } \\
\text { Status gizi kurang }\end{array}$ & $\begin{array}{c}198 \\
44\end{array}$ & $\begin{array}{l}81.8 \\
18,2\end{array}$ \\
\hline
\end{tabular}

Berdasarkan tabel 2 menunjukkan bahwa sebagain besar (57\%) baduta mempunyai faktor penyakit, Sebagian besar $(82.6 \%)$ ibu menggunakan fasilitas kesehtan untuk monitoring kesehatan dan pengobatan, sebagaian besar (76\%) ibu berpendidikan rendah (SMP dan SMA), sebagain besar $(65,9 \%)$ ibu mempunyai pengetahuan cukup tentang gizi 
anak, sebagaian besar $(66,1 \%)$ respoden mempunyai tanggungan lebih dari 5 orang, sebagaian besar $(52,1 \%)$ responden mempunyai pendapatan kurang dari UMR, sebagaian besar $(64.5 \%)$ ibu mempunyai budaya yang baik tentang makanan pada anak, dan sebagain besar $(81.8 \%)$ baduta dengan status gizi baik.

\section{Analisis Bivariat}

1. Faktor penyakit yang berhubungan dengan status gizi Baduta di Jombang tahun 2019.
Berdasarkan tabel 3 menunjukan sebanyak 70 dari $138 \quad(50,7 \%)$ baduta mempunyai penyakit yang sering di derita dengan baduta status gizi kurang. Hasil analisis uji Chi-Square dengna nilai $\rho=0,232$ lebih besar dari $\alpha=0,05$ artinya tidak ada hubungan yang signifikan antara penyakit yang pernah di derita dengan status gizi baduta. Hasil analisis diperoleh nilai $\mathrm{OR}=3,652$ artinya, penyakit yang pernah di derita baduta mempunyai peluang 3,652 kali pada balita status gizi baik.

Table 3. Tabulasi silang antara faktor penyakit dengan status gizi Baduta di kabupaten Jombang 2019

\begin{tabular}{|l|l|l|l|l|l|l|l|l|}
\hline \multirow{3}{*}{ Faktor penyakit } & \multicolumn{4}{|l|}{ Status gizi } & \multicolumn{2}{l|}{ Total } & \multirow{2}{*}{$\rho$} & \multirow{2}{*}{ OR } \\
\cline { 2 - 7 } & Baik & Kurang & \multicolumn{2}{|l|}{} & \\
\cline { 2 - 7 } & $\mathrm{f}$ & $\%$ & $\mathrm{f}$ & $\%$ & $\mathrm{f}$ & $\%$ & & \\
\hline ada & 68 & 49,3 & 70 & 50,7 & 138 & 100,0 & \multirow{3}{*}{0,232} & \multirow{3}{*}{3,652} \\
\hline Tidak & 60 & 57,7 & 44 & 42,3 & 104 & 100,0 & \\
\hline Total & 128 & 52,9 & 114 & 47,1 & 242 & 100,0 & & \\
\hline
\end{tabular}

Sumber : Data Primer 2019

2. Faktor penggunaan fasilitas layanan kesehatan dengan status gizi Baduta di Jombang

Tabel 4 Tabulasi silang hubungan antara penggunaan fasilitas kesehatan dengan status gizi baduta di Jombang 2019

\begin{tabular}{|c|c|c|c|c|c|c|c|c|c|}
\hline \multirow{3}{*}{$\begin{array}{l}\text { Fasilitas } \\
\text { kesehatan }\end{array}$} & \multicolumn{5}{|c|}{ Status gizi } & \multicolumn{2}{|c|}{ Total } & \multirow{3}{*}{$\rho$} & \multirow{3}{*}{ OR } \\
\hline & \multicolumn{2}{|c|}{ baik } & \multicolumn{3}{|c|}{ Kurang } & & & & \\
\hline & $\mathrm{f}$ & $\%$ & \multicolumn{2}{|c|}{$\mathrm{f}$} & $\%$ & $\mathrm{f}$ & $\%$ & & \\
\hline $\begin{array}{l}\text { Sering } \\
\text { menggunakan }\end{array}$ & 178 & 89 & 22 & 11 & 200 & & 100,0 & & \\
\hline $\begin{array}{l}\text { Jarang } \\
\text { menggunakan }\end{array}$ & 20 & 47,6 & 22 & 52,4 & 42 & & 100,0 & 0,014 & 9,816 \\
\hline Total & 198 & 81,8 & 44 & 18,2 & 242 & & 100,0 & & \\
\hline
\end{tabular}

Sumber : Data Primer 2019

Berdasarkan tabel 4 menunjukan sebagaian besar $(89 \%)$ ibu sering menggunakan fasilitas kesehatan dengan status gizi baduta baik sebanyak 178 dari 200 responden. Hasil analisis uji Chi-Square dengan nilai $\rho=0,012$ kurang dari $\alpha=0,05$ artinya ada hubungan yang signifikan antara penggunaan fasilitas kesehatan dengan status gizi baduta. Hasil analisis diperoleh pula nilai $\mathrm{OR}=9,816$ artinya baduta yang menggunakan fasilitas kesehatan mempunyai peluang 9,816 kali balita status gizi baik.

3. Faktor pendidikan ibu dengan status gizi Baduta di Jombang tahun 2019

Table 5. Tabulasi silang hubungan antara pendidikan ibu dengan status gizi Baduta di 2019

\begin{tabular}{|c|c|c|c|c|c|c|c|c|}
\hline \multirow{3}{*}{ Pendidikan } & \multicolumn{4}{|c|}{ Status gizi } & \multicolumn{2}{|c|}{ Total } & \multirow{3}{*}{$\mathrm{P}$} & \multirow{3}{*}{ OR } \\
\hline & \multicolumn{2}{|l|}{ baik } & \multicolumn{2}{|c|}{ kurang } & & & & \\
\hline & $\mathrm{f}$ & $\%$ & $\mathrm{f}$ & $\%$ & $\mathrm{f}$ & $\%$ & & \\
\hline Rendah & 163 & 88,6 & 21 & 11,4 & 184 & 100,0 & \multirow{3}{*}{0,366} & \multirow{3}{*}{$\begin{array}{l}1,15 \\
3\end{array}$} \\
\hline Tinggi & 35 & 60,3 & 23 & 39,7 & 58 & 100,0 & & \\
\hline Total & 198 & 81,8 & 44 & 18,2 & 242 & 100,0 & & \\
\hline
\end{tabular}

Sumber : Data Primer 2019 
Berdasarkan tabel 5 menunjukan sebagian besar $(88,6 \%)$ ibu berpendidikan rendahdengan baduta status gizi baik sejumlah 163 dari dari 184 responden. Hasil analisis uji Chi-Square dengan nilai $\rho=0,366$ lebihbesar dari $\alpha=0,05$. Artinya tidak ada hubungan yang signifikan antara pendidikan ibu dengan status gizi baduta. Hasil analisis diperoleh pula nilai $\mathrm{OR}=1,153$ artinya, ibu yang berpendidikan rendah mempunyai peluang 1,153 kali baduta status gizi baik.

4. Faktor pengetahuan ibu dengan status gizi Baduta di Jombang tahun 2019

Table 6 Tabulasi silang hubungan antara pengetahuan ibu dengan status gizi Baduta di Jombang tahun 2019

\begin{tabular}{|c|c|c|c|c|c|c|c|c|}
\hline \multirow{3}{*}{ Pengetahuan } & \multicolumn{4}{|c|}{ Status gizi } & \multicolumn{2}{|c|}{ Total } & \multirow{3}{*}{$\rho$} & \multirow{3}{*}{ OR } \\
\hline & \multicolumn{2}{|c|}{ Baik } & \multicolumn{2}{|c|}{ Kurang } & & & & \\
\hline & f & $\%$ & $f$ & $\%$ & $f$ & $\%$ & & \\
\hline Baik & 117 & 82,9 & 25 & 17,1 & 141 & 100,0 & & \\
\hline Cukup & 81 & 80,2 & 19 & 19,8 & 101 & 100,0 & 0,018 & 8,412 \\
\hline Total & 198 & 81,8 & 44 & 18,2 & 242 & 100,0 & & \\
\hline
\end{tabular}

Sumber: Data Primer 2019

Berdasarkan tabel 6. Menunjukan bahwa sebagain besar $(82,9 \%)$ ibu berpengetahuan baik dengan status gizi baik baduta ). Hasil ChiSquare dengan nilai $\rho=0,018$ kurang dari $\alpha=$ 0,05 artinya ada hubungan yang signifikan antara pengetahuan ibu dengan status gizi baduta. Hasil analisis diperoleh pula nilai $\mathrm{OR}=$ 8,412 artinya, ibu dengan pengetahuan baik mempunyai peluang 8,412 kali status gizi baik baduta.

5. Faktor tanggungan keluarga kurang dari 5 orang dengan status gizi Baduta di Jombang 2019

Tabel 7. Tabulasi silang hubungan antara tanggungan keluarga kurang dari 5 orang dengan status gizi Baduta di Jombang 2019

\begin{tabular}{|c|c|c|c|c|c|c|c|c|}
\hline \multirow{3}{*}{$\begin{array}{l}\text { Tanggungan } \\
\text { keluarga }\end{array}$} & \multicolumn{4}{|c|}{ Status gizi } & & & \multirow{3}{*}{$\rho$} & \multirow{2}{*}{ OR } \\
\hline & \multicolumn{2}{|c|}{ baik } & \multicolumn{2}{|c|}{ Kurang } & Total & & & \\
\hline & $\mathrm{f}$ & $\%$ & $\mathrm{f}$ & $\%$ & $\mathrm{f}$ & $\%$ & & \\
\hline$\geq 5$ & 46 & 56,1 & 36 & 43,9 & 82 & 100,0 & & 6.000 \\
\hline$<5$ & 152 & 95 & 8 & 5 & 160 & 100,0 & 0,040 & \\
\hline Total & 198 & 81,8 & 44 & 18,2 & 242 & 100,0 & & \\
\hline
\end{tabular}

Sumber: Data Primer 2019

Berdasarkan tabel 7 menunjukanhampir seluruhnya (95\%) tanggungan keluarga kurang dari 5 dengan status gizi baduta baik sebesar 52 dari 160 responden dengan nilai $\rho=0,046$ lebih kecil dari $\alpha=0,05$ artinya ada hubungan yang signifikan antara tanggungan keluarga kurang dari 5 orang dengan status gizi Baduta. Hasil analisis diperoleh pula nilai $\mathrm{OR}=6,000$ artinya keluarga yang mempunya tanggungan kurang dari 5 mempunyai peluang 6 kali baduta gizi baik.

6. Faktor pendapatan keluarga dengan status gizi Baduta di Jombang tahun 2019

Tabel 8 Tabulasi silang antara pendapatan keluarga dengan status gizi Baduta di Jombang tahun 2019

\begin{tabular}{|c|c|c|c|c|c|c|c|c|}
\hline \multirow{3}{*}{ Pendapatan } & \multicolumn{4}{|c|}{ Status gizi } & \multicolumn{2}{|c|}{ Total } & \multirow{3}{*}{$\rho$} & \multirow{3}{*}{ OR } \\
\hline & \multicolumn{2}{|c|}{ Baik } & \multicolumn{2}{|c|}{ kurang } & & & & \\
\hline & $\mathrm{f}$ & $\%$ & $f$ & $\%$ & $\mathrm{f}$ & $\%$ & & \\
\hline $\begin{array}{l}\text { Rendah } \\
(<\mathrm{UMK})\end{array}$ & 84 & 72,4 & 32 & 27,5 & 116 & 100,0 & & \\
\hline $\begin{array}{l}\text { Tinggi } \\
(\geq \mathrm{UMK})\end{array}$ & 114 & 90,5 & 12 & 9,5 & 126 & 100,0 & 0,038 & 3,116 \\
\hline Total & 198 & 81,8 & 44 & 18,2 & 242 & 100,0 & & \\
\hline
\end{tabular}

Sumber: Data Primer 2019 
Berdasarkan tabel 8 menunjukan hamper seluruhnya $(90,5 \%)$ pendapatan keluarga tinggi dengan status gizi baduta baik sebesar 114 dari 126 responden dengan nilai $\rho=0,038$ kurang dari $\alpha=0,05$ artinya ada hubungan yang signifikan antara pendapatan keluarga dengan status gizi Baduta. Hasil analisis diperoleh pula nilai $\mathrm{OR}=3,116$ artinya, pendapatan keluarganya tinggi (>UMK) mempunyai peluang 3.116 kali status gizi baik baduta

7. Faktor budaya tentang makanan dengan status gizi Baduta diJombang tahun 2019 .

Tabel 9 Tabulasi silang antara budaya tentang makanan dengan status gizi Baduta di Jombang tahun 2019

\begin{tabular}{|c|c|c|c|c|c|c|c|c|}
\hline \multirow{3}{*}{ Budaya } & \multicolumn{4}{|c|}{ Status gizi } & \multicolumn{2}{|c|}{ Total } & \multirow{3}{*}{$\rho$} & \multirow{3}{*}{ OR } \\
\hline & \multicolumn{2}{|c|}{ Baik } & \multicolumn{2}{|c|}{ kurang } & & & & \\
\hline & $\mathrm{f}$ & $\%$ & $\mathrm{f}$ & $\%$ & $\mathrm{f}$ & $\%$ & & \\
\hline baik & 138 & 88,5 & 18 & 11.5 & 156 & 100,0 & & \\
\hline $\begin{array}{l}\text { Kurang } \\
\text { baik }\end{array}$ & 60 & 69.8 & 26 & 30,2 & 86 & 100,0 & 0,048 & 2,226 \\
\hline Total & 198 & 81,8 & 44 & 18,2 & 242 & 100,0 & & \\
\hline
\end{tabular}

Sumber: Data Primer 2019

Berdasarkan tabel 9 menunjukan sebagian besar $(88,5 \%)$ ibu mempunyai budaya tentang makanan baik dengan status gizi baduta baik sebesar 138 dari 156 responden. Hasil analisis uji Chi-Square nilai $\rho=0,048$ kurang dari $\alpha=$ 0,05 artinya ada hubungan yang signifikan

\section{Analisis Multivariat}

Analisi faktor yang paling dominan yang mempengaruhi status gizi Baduta di Jombang tahun 2019. Di lakukan uji adalah variable yang antara budaya tentang makanan dengan status gizi Baduta. Hasil analisis nilai $\mathrm{OR}=2,226$ artinya, budaya tentang makan baik mempunyai peluang 2,226 kali status gizi baik baduta

Tabel 10 Analisis multivariat faktor-faktor yang berhubungan dengan status gizi baduta

\begin{tabular}{|l|l|l|l|l|}
\hline $\begin{array}{l}\text { Regresi } \\
\text { Logistik }\end{array}$ & Variabel & Koefisien & Sig. & $\operatorname{Exp}(\mathbf{B})$ \\
\hline Langkah 1 & Fasilitas kesehatan & 3.892 & 0,0365 & 8.235 \\
\cline { 2 - 5 } & pengetahuan & 1,987 & 0,0457 & 6,987 \\
\cline { 2 - 5 } & $\begin{array}{l}\text { Tanggungan } \\
\text { keluarga }\end{array}$ & 1.897 & 0,0351 & 4,982 \\
\cline { 2 - 5 } & Penghasilan & 3,986 & 0,0287 & 3.983 \\
\cline { 2 - 5 } & Budaya & 4,981 & 0,342 & 2,973 \\
\cline { 2 - 5 } & Konstanta & 0,773 & 0,873 & 1.845 \\
\hline
\end{tabular}

Berdasarkan tabel 10, variable yang significat di lakukan uji regresi logistic untuk menentukan variable yang paling dominan, dengan hasil variable penggunaan fasilitas Kesehatan yaitu $\rho$-value $=0,0365$ lebih kecil dari $\alpha \quad 0,05$ dengan OR 8.235 yang artinya

\section{PEMBAHASAN}

1. Factor penyakit yang berhubungan dengan status gizi Baduta terdapat hubungan, bila variable tidak ada hubungan (Pendidikan) tidak di lakukan uji. 
$=0,232$ lebih besar dari $\alpha=0,05$ artinya tidak ada hubungan yang signifikan antara penyakit yang pernah di derita dengan status gizi Baduta. nilai $\mathrm{OR}=3,652$ Penyakit yang pernah di derita baduta mempunyai peluang 3,652 kali pada balita status gizi baik

Penyakit yang sering terjadi pada masa baduta adalah penyakit Infeksi. Infeksi merupakan salah satu penyakit yang sering terjadi pada anak baduta, Banyak faktor yang mempengaruhi anak mengalami infeksi salah satunya adalah status gizi baduta yang kurang, Satus gizi kurang pada baduta banyak di pengaruhi dari bergai faktor antara faktor lingkungan, faktor imunitas anak sendiri, pola asuh ibu dalam memberikan makanan, pendapatan keluarga (Soetjiningsih dan Ranuh, 2014)

Masa pertumbuhan dan perkembangan pada anak memerlukan kecukupan gizi yang baik yang di gunakan untuk pertumbuhan dan perkembangan anak dan untuk meningkatkan system imunitas tubuh yang akan di gunakan untuk melawan suatu penyakit. Anak yang mendapatkan kecukupan gizi dalam masa pertumbuhannay akan memepunyai sattus gizi yang baik. Pada fase anak sedang mengalami fase tumbuh kembang yang pesat yang membutuhkan asupan gizi yang baik untuk mempertahankan dan meningkatkan satusu gizi dan kekebalan terhadap penyakit. Pada masa ini anak anak mudah terserang penyakit khususnya penyakit infeksi yang membutuhkan makanan yang bergizi untuk melawan penyakitnya. Penyakit infeksi yang sering menyerang anak baduta adalah ISPA, diare yang biasanya akan sembuh dengan pengobatan yang baik pada hari 3-5. Pada fase ini anak mempunya fase kejar tumbuh untuk mengganti fase yang di lalui saat sakit untuk mengejar pertumbuhan dan perkembangan yang terhambat saat anak mengalami sakit. Selama 35 hari anak mengalami sakit dan akan sembuh. Setelah pada hari ke 5 anak akan Kembali normal lagi untuk nafsu makannya, kadang setelah sembuh anak akan meningkat untuk nafsu makannya.

Pada masa kejar cepat seorang anak membutuhkan asupan gizi yang lebih untuk memperbaiki sel sel yang rusak dan karena sakit dan bertambahnya sel - sel untuk menuju pertumbuhan dan perkembangan yang optimal. Saat anak sakit sebagian besar akan menurunkan nafsu makan atau bahkan membuat seorang anak tidak mau makan, salah satu fungsi makan untuk mengganti sel yang rusak karena penyakit dan menambahnya jumlah sel bila tidak ada masukan makanan yang bergizi untuk hal tersebut akan menghancurkan simpanan lemak/ karbohidrat dan protein yang ada di tubuh anak untuk mencukupi kebutuahnnya. Pada anak yang sering menderita penyakit infeksi ringan akan mempengaruhi 3,652 kali status gizi anak menjadi kurang dibandingkan dengan anak yang jarang menderita sakit.

2. Faktor penggunaan fasilitas Kesehatan dengan status gizi Baduta di kabupaten Jombang tahun 2019

Berdasarkan tabel 4 menunjukan Sebagian besar (89\%) responden sering menggunakan fasilitas kesehatan dengan status gizi baik baik dengan nilai $\rho=0,012$ kurang dari $\alpha=0,05$. Artinya ada hubungan yang signifikan antara penggunaan fasilitas kesehatan dengan status gizi baduta, dengan nilai $\mathrm{OR}=9,816$ artinya baduta yang menggunakan fasilitas kesehatan mempunyai peluang 9,816 kali balita status gizi baik.

Penggunanan fasilitas kesehatan yang mudah di akses oleh masyarakat umum dan tersebar di seluruh kecatan dan desa adalah Puskesemas dengan segala kegiatan yang melibatkan pemberdayaan masyarakat dengan kegiatan antara lain adalah Posyandu.

Kemampuan suatu rumah tangga untuk mengakses fasilitas pelayanan kesehatan berkaitan dengan ketersediaan sarana pelayanan kesehatan serta kemampuan ekonomi untuk membayar biaya pelayanan. Pelayanan kesehatan sangat sensitif terhadap perubahan situasi ekonomi. Gangguan situasi ekonomi akan menggangu aksesibilitas masyarakat dan keluarga terhadap pelayanan kesehatan, contohnya: pelayanan imunisasi, perawatan berkaitan dengan pertumbuhan, morbiditas, dan mortalitas anak. Akses ke pelayanan kesehatan dilihat dari jarak dan waktu tempuh serta biaya yang dikeluarkan untuk mencapai pelayanan kesehatan. Jarak merupakan ukuran jauh dekatnya dari rumah/tempat tinggal seseorang ke pelayanan kesehatan terdekat. Jarak tempat tinggal responden ke pelayanan kesehatan merupakan salah satu faktor yang mempengaruhi penggunaan fasilitas kesehatan.

Pelayanan kesehatan yang dapat di akses oleh keluarga atau ibu untuk pemeliharaan dan peningkatan status kesehtan yaitu 
Puskesmas, Puskesmas keliling , Puskesmas Pembantu, Poyandu yang sudah ada di setiap kecamatan atau di desa dengan Posyandu masing2 yang akan melayani ibu dengan Badutanya setiap bulan. Di setiap desa juga terdapat bidan desa untuk memberikan pelayanan yang maksimal dan mendekati kepada keluarga atau ibu yang membutuhkan. Disamping itu pelayanan kesehataan juga dapat menggunakan praktik dokter yang ada di daerah masing- masing. BPJS bagi keluarga yang membutuhkan sudah tersebar keseluruh pelosok yang membantu masyarakat yang kurang mampu untuyk mudah menggunakan fasilitas kesehatannya. Fasilitas kesehatan telah di gunakan dengan baik oleh keluarga untuk meningkatkan status kesehatan anaknya. Ibu dengan baduta yang menggunakan fasilitas kesehatan dapat berupa puskesmas, Posyandu yang terdekat dengan rumahnya anaknya mempunyai peluang 9,816 kali status gizi baik di bandingkan dengan ibu yang kurang optimal dalam menggunakan pelayanan kesehatan.

Di dalam pelayanan kesehatan ibu mendapatkan fasilitas imunisasi pada anaknya yang berdampak untuk meningkatkan status kesehatan, menimbangkan anaknya rutin setiap bulan untuk monitor pertumbuhan dan perkembangannya. Pengobatan sederhana bila anak mengalami suatu penyakit, Pendidikan kesehatan yang berhubungan dengan status kesehatan anaknya yang bertujuan untuk meningkatakan pertumbuhan dan perkembangan yang optimal dan pemberdayaan ibu dalam stimulasi pertumbuhan dan perkembangan. Adanya program perbaikan gizi keluarga yang di tujukan untuk anak yang mengalami gangguan gizi agar meningkat status gizinya. Adanya pemberian vitamin A setiap bulan febuari dan agustus untuk meniongkatan system imun dan mencegah penytakit pada anak

3. Faktor Pendidikan ibu dengan status gizi Baduta di kabupaten Jombang tahun 2019

Berdasarkan tabel 5 menunjukan sebagian besar $(88,6 \%)$ ibu berpendidikan rendah dengan baduta status gizi baik sejumlah 163 dari dari 184 responden. Hasil analisis uji Chi-Square dengan nilai $\rho=0,366$ lebih besar dari $\alpha=0,05$. Artinya tidak ada hubungan yang signifikan antara pendidikan ibu dengan status gizi baduta. Hasil analisis diperoleh pula nilai OR $=1,153$ artinya, ibu yang berpendidikan rendah mempunyai peluang 1,153 kali baduta status gizi baik.

Pendidikan ibu mempengaruhi status gizi anak. Ibu dengan pendidikan rendah memiliki anak dengan angka mortalitas yang lebih tinggi dari pada anak dengan ibu berpendidikan tinggi (Adriani and Wirjatmadi, 2016). Platar belakang Pendidikan memberikan dasar seseorang untruk memberikan suatu respon terhadap masalah yang di hadapai. Pendidikan lebih tinggi akan memberikan respon yang lebih rasional terhadap informasi yang datang dan akan berfikir sejauh mana keuntungan yang mungkin diperoleh dari gagasan tersebut.

Pendidikan dibagi menjadi 2 yaitu pendidikan formal dan non formal. Pendidikan formal itu sendiri adalah jalur pendidikan yang terstruktur dan berjenjang yang terdiri atas pendidikan dasar (SD dan SMP dan sederajat ), Pendidikan menengah (SMA dan sederajat) dan Pendidikan tinggi (Pendidikan yang diadakan oleh perguruan tinggi Pendidikan non formal yaitu diselenggarakan bagi masyarakat yang memerlukan layanan pendidikan yang berfungsi sebagai pengganti, penambah pengetahuan yang dapat di di peroleh di luar bangku pendiidikan formal sesuai yang di butuhkan oleh ibu. Pendidikan non formal dapat di peroleh dengan mudah dan cepat pada masa sekarang dengan adanya kecanggihan alat komunikasi yang dapat di jangkau oleh masyarakat secara mudah, cepat dan murah sesuai dengan kebutuhan informasi yang di butuhkan. Ibu dapat mengakses cara memberikan makanan untuk meningkatkan status gizi dengan mudah dengan menggunkan fasilitas secara on line , waktunya bebas, topik yang di cari sesuai dengan kebutuhannya dan ibu ntidak memerlukan keluar rumah. Seorang ibu dapat belajar banyak secara in formal dengan zaman milineal sekarang, penggunakan alat komunikasi dapat mempermudah meningkatkan pengetahuan ibu dalam memberikan makanan yang bergizi pada anaknya untuk meningktkan status gizi. Di butuhkan motivasi yang tinggi dari ibu yang dapat di peroleh dari belajar sendiri atau berinteraksi dengan petuga kesehatan

Pendidikan formal tidak menjamin seorang ibu mempunyai kemampuan dalam merawat anaknya khusunya dalam pemberian makanan untuk meningkatkan status gizi . Pendidikan ibu rendah mungkin saat itu banyak factor yang mempengaruhi ibu tidak mengenyam Pendidikan formal yang cukup langsung menikah dan di hadapkan pada masalah 
keluarga. Seorang ibu dalam memberikan makanan bergizi dapat di pelajari secara mandiri atau belajar secara otodiktak bagaimna cara memberikan makan bergizi agar anak mempunyai status gizi baik. Ibu dengan Pendidikan Tinggi secara formal merasa usah memahami tentang memmberikan makan bergizi yang membuat ada keengannn untuk mencari informasi tentang cara memberikan makan bergizi. Pengetahuan tentang gizi dapat di peroleh ibu melalui pendidikan informal. ibu yang berpendidikan rendah mempunyai peluang 1,153 kali mempunyai anak baduta status gizi baik di bandingkan dengan pendidikan yang tinggi. Walaupun ibu berpendidikan rendah mempunyai baduta dengan gizi baik.

4. Faktor pengetahuan ibu dengan status gizi Baduta di kabupaten Jombang 2019

Berdasarkan tabel 6. Menunjukan bahwa sebagain besar $(82,9 \%)$ ibu berpengetahuan baik dengan status gizi baik baduta). Hasil ChiSquare dengan nilai $\rho=0,018$ kurang dari $\alpha=$ 0,05 artinya ada hubungan yang signifikan antara pengetahuan ibu dengan status gizi baduta. Hasil analisis diperoleh pula nilai $\mathrm{OR}=$ 8,412 artinya, ibu dengan pengetahuan baik mempunyai peluang 8,412 kali status gizi baik baduta.

Pengetahuan adalah suatu hasil dari rasa keingintahuan melalui proses sensoris, terutama pada mata dan telinga terhadap objek tertentu. Pengetahuan merupakan domain yang penting dalam terbentuknya perilaku terbuka atau open behavior Pengetahuan atau knowledge adalah hasil penginderaan manusia atau hasil tahu seseorang terhadap suatu objekmelalui pancaindra yang dimilikinya. Panca indra manusia guna penginderaan terhadap objek yakni penglihatan, pendengaran, penciuman, rasa dan perabaan. Pada waktu penginderaan untuk menghasilkan pengetahuan tersebut dipengaruhi oleh intensitas perhatiandan persepsi terhadap objek. Pengetahuan seseorang sebagian besar diperoleh melalui indra pendengaran dan indra penglihatan (Notoatmodjo, 2010). Hal ini berkaitan erat dengan wawasan pengetahuan mengenai sumber gizi dan jenis makanan yang baik untuk konsumsi keluarga. Kondisi demikian ini menyebabkan orang tua khususnya ibu kurang optimal dalam memenuhi kebutuhan gizi anak, sehingga menyebabkan anak mengalami stunting (Ngaisyah, 2015)
Pengetahuan ibu yang berkaitan dengan pemberian makanan bergizi pada baduta dapat melituti cara pemberian makanan yang dapat meningkatkan nafsu makan pada anak, jumlah makanan yang di berikan sesuai dengan usia anak, frekwensi makan anak dalam sehari minimal 5 kalai (3 kali makan pokok, 2 kali makan selingan), jenisnya yang beraneka ragam mengandung gizi seimbang (protein nabati/hewani, karbohidrat, vitamin dn mineral) yang aneka ragam. Pengetahuan seorang ibu untuk memberikan makanan bergizi pada anaknya dapat di peroleh melalui berbagai cara yaitu : media on line yang sekarang sudah mudah di akses oleh ibu untuk mendapatkan materi yang diinginkan sesuai kebutuhannya dengan mudah dan cepat yang akan mempengaruhi pengetahuan ibu dalam memberikan makanan yang bergizi kepada anaknya. Menghadiri atau mengikuti kegiatan kegiatan sosial yang berhubungan dengan kesehatannya khususnya cara memberikan makan bergizi yang sekarang sedang marak di lakukan oleh suatu organisasi sosial yang membantu pemerintah dalam meningkatkan peran serta masyarakat untuk meningkatkan status gizi anak dan keluarganya. Mengikuti kegiatan Posyandu yang rutin di lakukan oleh masyarakat dengan Puskesmas di mana terdapat meja 5 yang berisi kegiatan pemberian pendidikan kesehatan yang di butuhkan oleh masyarakat, dengan ibu aktif mengikuti kegiatan sosial yang berhubungan dengan kesehatan akan menambah pengetahuan ibu dalam memberikan makanan yang bergizi pada anaknya. Pengetahuan ibu yang baik tentang makan yang mempunyai peluang 8,412 kali status gizi baduta baik di bandingkan pengetahuan ibu yang kurang.

5. Faktor tanggungan keluarga dengan status gizi baduta

Berdasarkan tabel 7 menunjukan hampir seluruhnya (95\%) tanggungan keluarga kurang dari 5 dengan status gizi baduta baik sebesar 52 dari 160 responden dengan nilai $\rho=0,046$ lebih kecil dari $\alpha=0,05$ artinya ada hubungan yang signifikan antara tanggungan keluarga kurang dari 5 orang dengan status gizi Baduta. Hasil analisis diperoleh pula nilai $\mathrm{OR}=6,000$ artinya keluarga yang mempunya tanggungan kurang dari 5 mempunyai peluang 6 kali baduta gizi baik. 
Jumlah Tanggungan Keluarga adalah banyaknya jiwa yang dalam satu rumah tangga menjadi tanggungan kepala keluarga.Tanggungan adalah orang atau orangorang yang masih berhubungan keluarga atau masih dianggap berhubungan keluarga serta hidupnya pun ditanggung (Hanum, 2018). Jumlah tanggungan adalah banyaknya jumlah jiwa (anggota rumah tangga) yang masih menempati atau menghuni satu rumah dengan kepala rumah tangga, serta masih menjadi beban tanggungan rumah tangga dalam memenuhi kebutuhan sehari-hari. Jumlah tanggungan menurut Ahmadi (2007) dapat digolongkan sebagai berikut : (1) Tanggungan besar, apabila jumlah tanggungan $\geq 5$ orang.(2) Tanggungan kecil, apabila jumlah tanggungan $<5$ orang.

Jumlah tanggungan rumah tangga secara tidak langsung mempengaruhi risiko terjadinya status gizi kurang. Hal ini karena banyaknya jumlah tanggungan yang membuat kebutuhan dalam rumah tangga menjadi lebih banyak. Jumlah tanggung keluarga juga di pengerahui oleh tipe keluarga pada responden. Di Indonesi banyak keluarga yang masih tinggal dengan orang tua/ mertuanya yang di sebut nuclear family dalam satu rumah terdapat beberapa keluarga yang akan mempengaruhi pengeluaran yang harus di tanggung oleh kepala keluarga dan akan mempengaruhi daya beli dalam memberikan jenis makanan yang di berikan pada anggota keluarga khususnya pada anak Baduta yang sedang dalam masa pertumbuhan membutuhkan gizi yang seimbang, beraneka ragam dan berkecukupan sesuai dengan usia anak. Semakin banyak anggota keluarga yang menjadi tanggungan kepala keluarga akan semakin sedikit setiap anggota keluarga memperoleh bagiannya. Ibu dengan keluarga yang mempunyai tanggungan kurang dari 5 orang mempunyai peluang 6 kali anaknya mengalami gizi baik dibandingkan dengan keluarga yang menjadi tanggungan lebih dari 5 orang.

6. Faktor pendapatan keluarga dengan status gizi baduta di jombang tahun 2019

Berdasarkan tabel 7 menunjukan hampir seluruhnya (95\%) tanggungan keluarga kurang dari 5 dengan status gizi baduta baik sebesar 52 dari 160 responden dengan nilai $\rho=0,046$ lebih kecil dari $\alpha=0,05$ artinya ada hubungan yang signifikan antara tanggungan keluarga kurang dari 5 orang dengan status gizi Baduta. Hasil analisis diperoleh pula nilai $\mathrm{OR}=6,000$ artinya keluarga yang mempunya tanggungan kurang dari 5 mempunyai peluang 6 kali baduta gizi baik.

Tingkat pendapatan keluarga ditetapkan berdasarkan Upah Minimum Kabupaten (UMK) Kabupaten Jombang tahun 2020 yaitu sebesar Rp. Rp. 2.654.095, (Gubernur Jawa Timur, 2019). Pendapatan rumah tangga adalah pendapatan yang diterima oleh rumah tangga bersangkutan baik yang berasal dari pendapatan kepala rumah tangga maupun pendapatan anggota-anggota rumah tangga. BPS (Badan Pusat Statistik) yang menyatakan bahwa pendapatan keseluruhan jumlah penghasilan yang diterima oleh seseorang sebagai balas jasa berupa uang dari segala hasil kerja atau usahanya baik dari sektor formal maupun non formal yang terhitung dalam jangka waktu tertentu.

Pendapatan keluarga merupakan faktor yang turut menentukan status gizi balita. Berdasarkan pendapatan yang dimiliki oleh keluarga dapat mencerminkan tingkat kemampuan keluarga tersebut dalam konsumsi makanan sehari-hari. Adanya permasalahan gizi yang mempengaruhi tumbuh kembang anak disebabkan karena adanya krisis ekonomi dari keluarga yang erat kaitannya dengan pendapatan yang diterima dari keluarga tersebut.

Status gizi baduta dapat di pengaruhi secara tidak langsung karena pendapatan keluarga <UMK sehingga menyebabkan kurangnya daya beli makanan untuk memberikan makan yang bergizi sesuai kebutuhan baduta. Pendapatan yang baik di atas UMR akan mempunyai peluang 3.116 kali status gizi baik baduta.

7. Faktor budaya dengan status gizi baduta di kbaupaten Jombang tahun 2019

Berdasarkan tabel 9 menunjukan sebagian besar $(88,5 \%)$ ibu mempunyai budaya tentang makanan baik dengan status gizi baduta baik sebesar 138 dari 156 responden. Hasil analisis uji Chi-Square nilai $\rho=0,048$ kurang dari $\alpha=$ 0,05 artinya ada hubungan yang signifikan antara budaya tentang makanan dengan status gizi Baduta. Hasil analisis nilai $\mathrm{OR}=2,226$ artinya, budaya tentang makan baik mempunyai peluang 2,226 kali status gizi baik baduta. 
Indonesia yang terdiri dari sosiobudaya yang beraneka ragam, akan berpengaruh terhadap pola asuh yang berbeda-beda dan perlu mendapat perhatian berkaitan dengan prevalensi gizi buruk yang terjadi. Disamping itu Indonesia yang terdiri dari banyak pedesaan juga merupakan daerah dengan prevalensi penyakit pada balita yang tinggi atau sekitar $57,9 \%$ dapat mempengaruhi status gizi balitanya. (Senewe, Musadad and Manalu, 2011).

Indonesia terdiri dari bermacam-macam budaya termasuk di Jombang merupakan kabupaten yang mempunyai budaya bermacammacam dan tata kehidupan sosial yang berbeda pula, hal ini telah memberikan struktur sosial yang mempengaruhi menu makan maupun pola makannya, kecenderungan muncul dari suatu budaya terhadap makanan sangat bergantung pada potensi alamnya atau faktor pertanian yang dominan. Kebudayaan terjadi karena adanya perilaku atau kebiasaan masyarakat dalam suatu tempat, kemudian kebiasaan ini berkembang dari zaman ke zaman yang akan menurun pada keturunan mereka kadang masyarakat itu menganggap ada kekuatan lebih besar selain dari manusia yakni Allah.

Pengaruh budaya terhadap gizi ada pengaruh yang postif dan negative terhadap status Kesehatan baduta. Pengaruh negatifnya munculnya masalah kekurangan gizi di masyarakat sekitar karena masyarakat sulit meninggalkan kebiasaan-kebiasaan mereka, mereka lebih percaya pada hal-hal yang di anggap tabu dalam budaya mereka sehingga apa yang sebenarnya tubuh butuhkan tidak terpenuhi sehingga banyak menimbulkan penyakit misalnya anak baduta tidak boleh makan ikan karena menyebabkan cacingan. Ikan merupakan sumber protein hewani yang di butuhkan oleh tubuh. Tidak boleh makan sayuran dan buahbuahan karen abisa menyebabkan diare. Sayuran dan buah-buahan merupakan suber vitamin dan mineral yang sangat baik. ibu dapat menanggapi budaya dengan bijak memlih jenis makanan yang bergizi yang di butuhkan oleh anak tampa ada bertentangan dengan budaya yang ada di lingkungannya.

Pengaruh Budaya positif akan meningkatan pemberian makanan pada anaka misalnya: anak karena titipan Alaah harus mendapatkan makan yang baik, bapak ibunya mengalah. Bila di tinjau dari sisi kesehatan, seorang anak sedang dalam pertumbuhan dan perkembangan membutuhkan makakan bergizi, bapak dan ibu sebagai orang dewasa sudah melalui fase pertumbuhan perkembangan cukup mendapatkan makanan yang berfungsi menggantikan sel- sel yang mati, Budaya yang kurang baik adalah anak tidak boleh makan ikan laut takut terjadi gatal, di dalam ilmu kesehatan kemungkinan ada beberapa anak yang alergi dnegan ikan laut tetapi ada beberapa anak yang tidak mempunyai alergi dapat di berikan ikan laut, yang alergi dengan ikan laut proten hewani dapat diganti dengan jenis yang lain agar anak mendapatkan gizi seimbang. Budaya dalam memberikan makan yang baik akan mempunyai peluang 2,226 kali status gizi baik baduta di bandingkan dengan budaya dalam memberikan makan yang kurang baik.

Pemberian makanan pada anak baduta juga di pengaruhi oleh norma budaya setempat Tradisi kuliner suatu daerah berbeda dengan tradisi kuliner daerah lain. Dalam suatu masyarakat menghidangkan makanan tergantung pada pola makan keluarga yang berasal dari kelompok etnis dan keagamaan yang sama dan menempati posisi sosial ekonomi yang sama. Kebiasaan makan juga berhubungan dengan jaringan sosial anggota kelompok dalam menghidangkan jenis makanan dalam keluarga. Kebiasaan menghidangkan makanan juga dipengaruhi oleh pendidikan formal orang yang menyiapkan makanan. Budaya dalam pemberian makan pada anak baduta juga di pengaruhi oleh kepercayaan dan kenyakinan yang di anut oleh ibu dan keluarga yang akan mempengaruhi seorang ibu dalam memberikan makanan pada anaknya.

8. Faktor yang paling dominan dengan satus gizi baduta

Berdasarkan tabel 10, variable yang significat di lakukan uji regresi logistic untuk menentukan variable yang paling dominan, dengan hasil variable penggunaan fasilitas Kesehatan yaitu $\rho$-value $=0,0365$ lebih kecil dari $\alpha \quad 0,05$ dengan OR 8.235 yang artinya penggunaan fasilitas kesehatan mempunyai peluang memiliki baduta dengan status gizi baik sebesar 8.235 kali dibandingkan dengan kurang menggunakan fasilitas kesehatan

\section{KESIMPULAN}

Simpulan tentang hasil penelitian faktor yang mempengaruhi ibu dalam pemberian nutrisi pada baduta di kabupaten jombang tahun 2019 adalah: 
1) Faktor penyakit, pendidkan ibu tidak ada hubungan dengan status gizi baduta

2) Faktor penggunaan fasilitas kesehatan, pengetahuan ibu tentang nutrisi, tanggungan keluarga, penghasilan keluarga dan budaya tentang pemberian makan dengan status gizi baduta.

3) Faktor dominan yang ada hubungannya dengan status gizi baduta adalah penggunaan fasilitas kesehatan

\section{SARAN}

Ibu lebih di sarankan untuk mengoptimalkan manfaat fasilitas pelayanan kesehatan yang ada di sekitar tempat tinggal untuk meningkatakan pemberian makanan bergizi melalui komunikasi informasi edukasi yang terstrutur dan terjadwal. Dapat mengembangkan variabel lebih kompleks dan dalam untuk mengembangkan faktor yang mempengaruhi status gizi baduta

\section{DAFTAR PUSTAKA}

Adriani, M. and Wirjatmadi, B. (2016) Pengantar Gizi Masyarakat. Jakarta: Prenada Media.

Ahmadi, A. (2007) Psikologi Sosial. Edisi Revisi. Jakarta: Rinek Cipta.

Ali, S. (2013) 'A Brief Review of Risk-Factors for Growth and Developmental Delay Among Preschool Children in Developing Countries', Advanced Biomedical Research, 2(1), p. 91. doi: 10.4103/2277-9175.122523.

Badan Penelitian dan Pengembangan Kesehatan (2019) 'Laporan Nasional Riset Kesehatan Dasar 2018'. Jakarta: Lembaga Penerbit Badan Penelitian dan Pengembangan Kesehatan, p. 198.

Dinas Kesehatan Kabupaten Jombang (2018) Profil Kesehatan Kabupaten Jombang 2018. Jombang.

Gubernur Jawa Timur (2019) Keputusan Gubernur Jawa Timur Nomor 568 tentang Upah Minimum Kabupaten/Kota di Jawa Timur Tahun 2020. Surabaya.

Hanum, N. (2018) 'Pengaruh Pendapatan, Jumlah Tanggungan Keluarga Dan Pendidikan Terhadap Pola Konsumsi Rumah Tangga Nelayan Di Desa Seuneubok Rambong Aceh Timur',
Jurnal Samudra Ekonomika, 2(1), pp. 75-84.

Hidayat, A. A. (2014) Metode Penelitian Kebidanan dan Teknik Analisa Data. Jakarta: Salemba Medika.

Khomsan, A. (2012) Ekologi Masalah Pangan, Gizi, dan Kemiskinan. Bandung: Alfabeta.

Ngaisyah, R. D. (2015) 'Hubungan Sosial Ekonomi Dengan Kejadian Stunting Pada Balita Di Desa Kanigoro, Saptosari, Gunung Kidul', Jurnal Medika Respati, X(4), pp. 65-70.

Notoatmodjo, S. (2010) Promosi Kesehatan dan Ilmu Perilaku. Cetakan I. Jakarta: PT. Rineka Cipta.

Senewe, F. P., Musadad, A. D. and Manalu, H. S. P. (2011) 'The Effect of Environment for Children Under-Five Morbidity Status in Disadvanteged Region 2008', Jurnal ekologi Kesehatan, 10(1), pp. 54-64.

Septikasari, M. (2018) Status Gizi Anak dan Faktor yang Mempengaruhi. Yogyakarta: UNY Press.

Soetjiningsih and Ranuh, I. N. G. (2014) Tumbuh Kembang Anak. Jakarta: EGC.

Supariasa, I. D. N., Fajar, I. and Bakri, I. (2001) Penilaian Status Gizi. Jakarta: EGC. 